UDK 811.163.42’367.335

Izvorni znanstveni rad

Rukopis primljen 4. I. 2019.

Prihvaćen za tisak 28. V. 2019.

https://doi.org/10.31724/rihjj.45.2.15

\title{
Ana Matić
}

Edukacijsko-rehabilitacijski fakultet Sveučilišta u Zagrebu

Borongajska cesta 83 f, HR-10000 Zagreb

ana.matic@erf.hr

\section{Jana Willer Gold}

University College London

Chandler House 2, Wakefield Street, GB-WC1N 1PF London

j.willer-gold@ucl.ac.uk

\section{Marijan Palmović}

Edukacijsko-rehabilitacijski fakultet Sveučilišta u Zagrebu

Borongajska cesta 83 f, HR-10000 Zagreb

marijan.palmovic@erf.hr

\section{Anita Peti-Stantić}

Filozofski fakultet Sveučilišta u Zagrebu

Ivana Lučića 3, HR-10000 Zagreb

anita.peti-stantic@ffzg.hr

\section{VEZANJE RELATIVNE REČENICE NA KOORDINIRANU SKUPINU U HRVATSKOME: PSIHOLINGVISTIČKI POGLED ${ }^{1}$}

Pitanja o pozadinskim procesima automatske obrade i interpretacije rečenica, odnosno jezično-specifičnim čimbenicima koji uvjetuju te procese, već su dugi niz godina aktualna tema brojnih psiholingvističkih istraživanja. Jedna od struktura koja je doprinijela novijim spoznajama jest relativna rečenica i pitanje procesa u podlozi vezanja relativne rečenice na odgovarajućega antecedenta.

S obzirom na to da međusobni odnos imenica u imenskoj skupini može utjecati na obradu rečenice, a s druge je strane upravo utjecaj toga odnosa nedovoljno razjašnjen, u ovome se istraživanju ispituje obrada relativnih rečenica u hrvatskome te preferencije vezanja

\footnotetext{
1 Istraživanje o kojem se izvještava u ovom radu provedeno je u okviru istraživačkog projekta Hrvatske zaklade za znanost IP-2016-1210 Modeliranje mentalne gramatike hrvatskoga: ograničenja informacijske strukture; istraživačkog projekta Zaklade Leverhulme RPG-2018-300 Experimental Verification of Agreement Mismatches: from Slavic to Bantu.
} 
izvornih govornika na primjerima u kojima je antecedent koordinirana skupina. U skladu s time, dva su glavna cilja rada: 1) ispitati koji element koordinirane imenske skupine modificira relativna rečenica i 2) istražiti koja ograničenja utječu na odabir antecedenta relativne rečenice.

U istraživanju su sudjelovale 62 odrasle osobe, izvorni govornici hrvatskoga, a ispitivanje je provedeno dvjema metodama - ispunjavanjem upitnika prosudbe i mjerenjem pokreta očiju tijekom čitanja u stvarnome vremenu. Rezultati upitnika, tj. odabira antecedenta, pokazuju da vezanje relativne rečenice na linearno bližu sastavnicu prevladava nad vezanjem na hijerarhijski višu sastavnicu subjekta glavne rečenice. Podatci dohvaćeni objema metodama dodatno pokazuju da je odabir antecedenta s jedne strane olakšan sročnošću, dok su s druge strane raznovrsnost strategija i višestruka mogućnost interpretacije uzrokom teškoća $u$ obradi.

Provedeno istraživanje upućuje na potrebu za ispitivanjem jezično-specifičnih čimbenika koji utječu na odabir i način vezanja relativne rečenice s ciljem širenja spoznaja o jezičnoj obradi općenito, kao i za sustavnim eksperimentalnim istraživanjima različitih fenomena u pojedinačnim jezicima.

\section{Uvod}

\subsection{Sintaktička obrada}

Iz literature je poznato da sintaktička obrada podrazumijeva postupne stadije u izgradnji sintaktičkih struktura tijekom procesa razumijevanja jezika (van Gompel i Pickering 2007). Ti procesi imaju vremensku dimenziju, a jedno od njihovih najvažnijih obilježja jest međusobno nadograđivanje. Unatoč brojnim istraživanjima, mentalni procesi u pozadini sintaktičke obrade ostaju slabo poznatima. Stoga je u psiholingvistici i dalje aktualno pitanje što pokreće sintaktičku obradu, odnosno na koje se obavijesti u tome procesu govornici oslanjaju i u kojem trenutku (Eysenck i Keane 2015). S vremenom su razvijene brojne teorije sintaktičke obrade, a modeli koji proizlaze iz tih teorija, koliko god raznoliki, uglavnom se mogu svrstati u tri osnovne kategorije, i to: (1) modele usmjerene na univerzalnost $\mathrm{u}$ mehanizmima sintaktičke obrade (univerzalni ili parametrizirani modeli); (2) modele usmjerene na vremenski slijed pristupanja strukturnim i značenjskim razinama obavijesti prilikom obrade (serijalni i paralelni modeli); (3) modele usmjerene na načine organizacije razina obavijesti (modularni i interaktivni modeli) (v. Fernández 2003, Papadopoulou 2006, Eysenck i Keane 2015). 
Samo bavljenje serijalnošću i paralelizmom ili modularnošću i interaktivnošću u obradi ne otvara prostor jasnim predviđanjima sintaktičke obrade u pojedinim jezicima, kao ni razrješavanju pitanja o čemu u strukturi jezika ovisi ta obrada. Prevladavajućim pristupom u obradi dugo se smatrao pristup dominacije sintakse (engl. syntax first; Fodor 1983) prema kojemu se govornici svih jezika u obradi oslanjaju isključivo na hijerarhijsku strukturu, a ne na značenje. Iz toga pristupa proizlazi da je proces razumijevanja rečenica u svim jezicima univerzalan te da ovisi o strukturi rečenice, odnosno da je vođen načelom lokalnosti (engl. locality principle; Frazier i Fodor 1978, Frazier 1979) ili recentnosti (engl. recency; Gibson 1998). Primjerice, u engleskome se jeziku u razumijevanju rečenica vrlo bitnim pokazao redoslijed konstituenata, $\mathrm{tj}$. pokazalo se da se svaki sljedeći konstituent u rečenici uvijek veže na posljednju riječ, onu koja se trenutno obrađuje (Frazier 1979, Carreiras i Clifton 1999). Ipak, sve je veći broj istraživanja u drugim jezicima navedene postavke počeo dovoditi u pitanje pa se započelo s provedbom istraživanja koja su se u većoj mjeri usmjerila na obilježja strukture pojedinoga jezika i njihov utjecaj na obradu. Jedna od struktura koja je uvelike doprinijela novom smjeru istraživanja upravo je relativna rečenica i pitanje procesa u podlozi vezanja relativne rečenice na odgovarajućeg antecedenta.

\subsection{Obrada i tumačenje relativnih rečenica}

Relativne rečenice prisutne su u većini jezika i upravo se stoga smatraju ,idealnima za ispitivanje sintaktičke obrade i međujezičnih varijacija" (Cuetos i dr. 1996). Kako bi bila usporediva, međujezična se psiholingvistička istraživanja temelje na relativnim rečenicama koje omogućuju manipulaciju mjestom na kojemu je pojedina informacija dostupna govorniku. U takvim se istraživanjima stoga najčešće ispituju obrada i tumačenje rečenica koje dozvoljavaju višestruku mogućnost interpretacije, odnosno onih u kojima relativnoj rečenici prethode složene imenske skupine, pri čemu je nejasno koju od dviju imenica relativna rečenica modificira, uzimajući je za svojega antecedenta (1a). Obrada se takvih rečenica potom uspoređuje s obradom rečenica u kojima je modifikacija jasna, što uslijed manipulacije morfološkim obilježjima (sročnost u rodu ili broju) (1b), što uslijed manipulacije prihvatljivošću s obzirom na enciklopedijsko znanje govornika (1c). Rezultati opisanih psiholingvističkih istraživanja pružaju podatke o preferencijama vezanja na jednoga od dva antecedenta. 
(1) ${ }^{2}$ a. Netko je pucao na sluškinju ${ }_{1}$ (od) glumice ${ }_{2}$ koja $_{1 / 2}$ je stajala na balkonu.

b. Netko je pucao na sluškinju ${ }_{1}$ (od) glumca koja $_{1}$ je stajala na balkonu.

${ }^{3} \mathrm{c}$. Netko je opomenuo oca $(\mathrm{od})$ sina $_{2} \mathrm{koji}_{2}$ je išao u školu.

Provedenim istraživanjima pokazano je kako je vezanje na linearno bližu imenicu, osim engleskomu, svojstveno i brazilskomu portugalskom (Miyamoto 1998), arapskomu (Abdelghany i Fodor 1999), švedskomu, norveškomu i rumunjskomu (Ehrlich i dr. 1999), kao u primjeru (2a), dok je istraživanjima odabira antecedenta u španjolskome jeziku (Cuetos i Mitchell 1988, Grillo i Costa 2014) utvrđeno kako se govornici toga jezika ne vode načelom recentnosti, već su osjetljivi na druga obilježja odnosa složenih imenskih skupina. Naime, prilikom obrade relativnih rečenica sa složenom imenskom skupinom govornici španjolskoga relativnu rečenicu vežu na hijerarhijski udaljeniju imenicu, kao u primjeru (2b).

(2) a. Someone shot the maid $_{1}$ of the actress that $_{2}$ was $_{2}$ standing on the balcony.

b. Alguien disparó contra la criada de la actriz $\mathbf{q}_{2} \mathbf{q u e}_{1}$ estaba $_{1}$ en el balcón.

Do sličnih se rezultata došlo u jezicima poput nizozemskoga (Brysbaert i Mitchell 1996), njemačkoga (Hemforth i dr. 1998), grčkoga (Papadopoulou i Clahsen 2003), pa i hrvatskoga (Lovrić i Fodor 2000, Matić 2018). Iako je jasno da suprotstavljeni rezultati proizlaze iz različitih struktura spomenutih jezika, nedovoljno je razjašnjeno koja ograničenja ili unutarjezični čimbenici utječu na odabir antecendenta, posebice u morfološki razvedenim jezicima poput hrvatskoga. Zbog toga raste broj istraživanja koja istražuju unutarjezične i međujezične odnose.

Pokazalo se da različita obilježja poput duljine glavne i relativne rečenice (primjerice, Hemforth i dr. 2015), vrste i statusa relativizatora (Hemforth i dr. 1998) ili međusobnoga odnosa imenica u složenoj imenskoj skupini koje prethode relativnoj rečenici (primjerice, Frazier i Clifton 1996) donekle utječu na obradu i tumačenje složene relativne rečenice. Naime, ako su imenice koje prethode relativnoj rečenici u sintagmatskome odnosu (primjerice, genitivni odnosi za izražavanje građe, dijela cjeline i svojstva), antecedentom se može smatrati linearno udaljenija, ali ujedno i hijerarhijski viša imenica koja je glava složene

\footnotetext{
2 Prema originalnom primjeru iz Traxler i dr. (1998). N. B., konstrukcije od + genitiv u hrvatskome se izbjegavaju.

3 Vlastiti primjer.
} 
imenske skupine. S druge strane, istraživanja su potvrdila da se vezanje mijenja ako imenice nisu dijelom jedinstvene cjeline (primjerice, prijedložni izrazi ili koordinirane skupine) (v. i Frazier i Clifton 1997, Traxler i dr. 1998). Ipak, općenite je zaključke teško donositi zbog često proturječnih rezultata koji nisu nužno posljedica samo različitih jezičnih struktura nego i eksperimentalnih nacrta pojedinačnih istraživanja.

U većini se indoeuropskih jezika struktura relativne rečenice izvornomu govorniku pokazala najsloženijom za obradu i razumijevanje, i na konceptualnoj, i na jezičnoj razini. U prilog složenosti te strukture govore i rezultati sve većega broja razvojnih studija i studija u kojima se uspoređuju populacije uredna i narušena jezičnoga statusa (Friedmann i Novogrodsky 2004, Balija i dr. 2012, Matić i Kuvač Kraljević 2017). Navedena istraživanja potvrđuju i da su objektne relativne rečenice značajno zahtjevnije za obradu od subjektnih, da u većoj mjeri opterećuju radnu memoriju i da se razvojno kasnije usvajaju (ibid.). No, unatoč velikim zahtjevima obrade, relativna je rečenica razmjerno česta u hrvatskome. Razlozi su, između ostaloga, nepostojanje struktura koje su u drugim jezicima njezini funkcionalni ekvivalenti, primjerice participi i gerundi (Kordić 1995: 42).

Razvidno je da su dosadašnja istraživanja preferencija vezanja relativnih rečenica usmjerena prvenstveno na složenu dvoimensku skupinu u kojoj je hijerarhijski viši element ujedno i glava. Stoga je interes ovoga istraživanja usmjeren na drugu vrstu dvoimenskih skupina, koordiniranu imensku skupinu, u kojoj hijerarhijski viši element nije ujedno i glava. Ovo naime doprinosi strukturno neutralnijemu odnosu dvaju potencijalnih antecedenata koje modificira relativna surečenica.

\subsection{Koordinirana skupina i strategije sročnosti}

Nedavna su istraživanja slaganja predikata s koordiniranom imenskom skupinom uputila na značajnu ulogu linearnosti u obradi sročnosti, što je dovelo u pitanje teorijske modele u kojima se sročnost zasnivala isključivo na hijerarhijskim odnosima i sintaktičkim operacijama (Marušič, Nevins i Badecker 2015, Willer Gold i dr. 2018). Podatci su prikupljeni opsežnom studijom koja je sustavnom primjenom metode potaknute proizvodnje na skupini južnoslavenskih jezika ispitala slaganje predikata s koordiniranom imenskom skupinom (Willer Gold i 
dr. 2016). Sudionicima je toga istraživanja zadatak bio naglas pročitati rečenicu prikazanu na zaslonu računala čiji je subjekt bila neživa imenica muškoga roda u jednini (npr. Dogovor je pomaknut na petak.), nakon čega bi se na zaslonu prikazala koordinirana skupina (npr. Sjednice i vijeća) koju je trebalo umetnuti na mjesto subjekta prethodno pročitane rečenice te tako prilagođenu rečenicu izgovoriti naglas (npr. Sjednice i vijeća pomaknut? su na petak.). Budući da je u istraživačkome fokusu bilo razlučiti s kojim se elementom koordinirane skupine slaže predikat, nakon transkripcije i kodiranja podataka, kao zavisna se varijabla uzeo rod na predikatnome participu. Usporedba roda na predikatnome participu s onim na konjunktima koordinirane skupine omogućava iščitavanje one koja upravlja slaganjem. U svrhu iscrpnoga prikupljanja podataka, u eksperimentu je upotrijebljen $3 \times 3$ faktorijalni nacrt u kojem se rod prvoga konjunkta [m; ž; sr] križao s rodom drugoga konjunkta [m; ž; sr], rezultirajući s devet uvjeta podudarnoga i nepodudaranoga obilježja roda konjunkata koordinirane skupine. Kombinacija konjunkata u ženskome i srednjemu rodu najinformativniji je uvjet koji osigurava jednoznačno iščitavanje koji element upravlja slaganjem: čitava koordinirana skupina (3a), hijerarhijski viši (3b) ili linearno bliži konjunkt (3c) (Willer Gold i dr. 2016). ${ }^{4}$ U spomenutome je uvjetu zabilježena proizvodnja sva tri roda na predikatnome participu (v. \% u (3)), čime se pokazalo da južnoslavenski jezici uz očekivano „neutralno” ili „zadano” (engl. default) slaganje u muškome rodu s čitavom koordiniranom skupinom dopuštaju i individualno slaganje sa svakim od dvaju elemenata koordinirane skupine. ${ }^{5}$

(3) a. ž. i s. r.: Sjednice i vijeća pomaknuti su na petak. (36\%)

b. ž. i s. r.: Sjednice i vijeća pomaknute su na petak. (11\%)

c. ž. i s. r.: Sjednice i vijeća pomaknuta su na petak. (53\%)

U širem je kontekstu istraživanja sročnosti sa strukturno složenim subjektima važno istaknuti da je i u drugim jezicima zabilježen viši postotak slaganja $\mathrm{s}$ linearno bližim elementom u usporedbi s hijerahijski višim (usp. \% u (3)) u primjerima u kojima je subjekt koordinirana skupina. Naime, slična je tendencija prema linearnome slaganju s koordiniranom skupinom uočena u istraživanju provedenom na engleskome jeziku u kojemu se uspoređivao učinak privlačenja

Uvjet muški i muški rod najmanje je informativan iz razloga što je zabilježeni rod na participskome predikatu isključivo muški rod što onemogućuje jednoznačno iščitavanje elementa koji upravlja slaganjem.

5 Za teorijski okvir vidi Marušič i dr. (2015), usp. Bošković (2009) i Murphy i Puškar (2017). 
(engl. attraction errors; Bock i Muller 1991, Franck, Vigliocco i Nicol 2002) u uvjetu u kojemu je subjekt složena imenska skupina (4a) nasuprot uvjeta u kojemu je subjekt koordinirana skupina (4b) (Keung i Staub 2018).

(4) a. *The key to the cabinets are...

b. *The keys and the cabinet is...

Uporabom kombinirane metodologije - zadatak prisilnoga odabira (engl. forced choice) i metoda praćenja pokreta očiju - Keung i Staub (2018) potvrdili su viši postotak netočnoga slaganja s linearno bližim konjunktom, ali i olakšanu obradu takvoga tipa slaganja kada je subjekt koordinirana skupina (4b) u usporedbi s uvjetom (4a) u kojemu je subjekt složena imenska skupina. To istraživanje prvenstveno upućuje na potrebu za širenjem rasprave o strukturnoj složenosti koordinirane skupine u usporedbi s drugim tipovima složenih dvoimenskih skupina i dodatno naglašava potrebu za razlikovanjem linearne sročnosti koja je uvriježeni, gramatikalizirani proces $(3 \mathrm{c})$ od one koja je rezultat pogreške $u$ proizvodnji (4b).

Imajući na umu da se u morfološki razvedenim jezicima poput hrvatskoga slaganje $u$ rodu (i broju) ostvaruje između antecedenta i relativne zamjenice te da je $u$ dosadašnjim istraživanjima visine vezanja dominirala složena imenska skupina (v. poglavlje 1.2.), vrijedno je istražiti utjecaj sročnosti na visinu vezanja relativne rečenice kojoj prethodi koordinirana skupina.

\section{Istraživačko pitanje i pretpostavke istraživanja}

Na temelju spoznaja iznesenih u uvodnome poglavlju te s obzirom na širinu doprinosa koje otvorenim pitanjima može ponuditi istraživanje hrvatskoga jezika, u ovome se radu postavljaju dva istraživačka pitanja s obzirom na preferencije vezanja:

(I.) Koji element koordinirane imenske skupine modificira relativna rečenica?

(II.) Koja ograničenja utječu na odabir antecedenta relativne rečenice?

Prvo se pitanje odnosi na dvije dosad opisane preferencije vezanja na dvoimensku skupinu: (i) vezanje na linearno bližu imenicu (3c) i (ii) vezanje na hijerar- 
hijski višu imenicu (3b). Kada je riječ o koordiniranoj skupini, važno je istaknuti da se neovisno o ostvaraju sročnosti (3) prvenstveno uspostavlja složena veza između predikata i subjekta, tj. čitave koordinirane skupine (3') (v. npr. Marušič i dr. 2015). Zbog ove se složene veze između antecedenata i predikata otvara i treća mogućnost: (iii) vezanje na čitavu koordiniranu skupinu (3'; v. i 3a).

(3') a. [Sjednice i vijeća $]_{i}$ pomaknuti ${ }_{i}$ su na petak.

b. $[\text { Sjednice i vijeća }]_{i}$ pomaknute $_{i}$ su na petak.

c. $[\text { Sjednice i vijeća }]_{\mathbf{i}}$ pomaknuta $_{\mathrm{i}}$ su na petak.

Drugo se pitanje odnosi na čimbenike koji potencijalno doprinose ili utječu na odabir antecedenta, primjerice sročnost. Budući da se u hrvatskome jeziku antecedent i relativna zamjenica slažu u rodu, no ne nužno i u broju i padežu, sročnost se nameće kao jedan od čimbenika koji vrijedi provjeriti. Na temelju rezultata sročnosti predstavljenih u poglavlju 1.3. predviđa se da će (1) odabir čitave koordinirane skupine i linearno bliže imenice za antecedenta relativne zamjenice biti relativno češći te da će olakšati obradu vezanja relativne rečenice, dok se na temelju dosadašnjih istraživanja o visini vezanja relativnih rečenica sa složenim imenskim skupinama u hrvatskom jeziku predstavljenih u poglavlju 1.2. predviđa da će (2) za antecedenta biti odabrana hijerarhijski viša imenica te da će (3) objektna relativna surečenica koja modificira subjekt glavne rečenice otežati obradu.

\section{Metode}

\subsection{Sudionici}

Istraživanje je provedeno dvjema metodama, ispunjavanjem upitnika prosudbe i mjerenjem pokreta očiju (MPO), pri čemu su istraživački materijali (rečenični podražaji) u dvama ispitivanjima bili ujednačeni. Kako bi se izbjegla upoznatost sudionika s materijalom, različite su osobe sudjelovale $u$ ispunjavanju upitnika i u istraživanju mjerenja pokreta očiju. U tim je dvjema skupinama bio proporcionalan broj sudionika muškoga i ženskoga spola razmjerno slične dobi i stupnja obrazovanja. U istraživanju su sudjelovale 62 osobe, izvorni govornici hrvatskoga, bez povijesti neuroloških oštećenja i razvojnih odstupanja. U skladu 
s etičkim načelima, svi su prethodno upoznati s istraživačkim ciljem te su potpisali suglasnost za sudjelovanje. Zajamčena im je anonimnost, a u svakome su se trenutku mogli povući iz ispitivanja bez obveze navođenja razloga povlačenja. Budući da je za mogućnost prikupljanja i kasnije obrade podataka pomoću mjerenja pokreta očiju bilo ključno da sudionici nemaju dioptriju i druga oštećenja oka i/ili vida koja mogu onemogućiti kalibraciju na uređaju i remetiti mjerenje, svi su sudionici imali neoštećen vid.

U oba je ispitivanja sudjelovao jednak broj osoba, studenata različitih fakulteta Sveučilišta u Zagrebu (upitnik prosudbe; $N=31$ i postupak mjerenja pokreta očiju; $N=31$ ). Podatci o sudionicima (spol i dob) prikazani su u Tablici 1.

Tablica 1. Obilježja (spol i dob) svih sudionika istraživanja

Sudionici Spol Dob

\begin{tabular}{llllllll} 
& $\mathrm{N}$ & $\mathrm{M}$ & $\mathrm{Z}$ & Sr. dob & SD & Min & Maks \\
\hline Upitnik & 31 & 8 & 23 & $24 ; 4$ & 4,81 & $19 ; 00$ & $41 ; 00$ \\
\hline & & & & & & & \\
MPO & 31 & 8 & 23 & $21 ; 4$ & 1,46 & $19 ; 11$ & $25 ; 08$
\end{tabular}

\subsection{Materijali i postupak ispitivanja}

Za potrebe istraživanja oblikovane su 24 rečenice, odnosno ispitna podražaja. Te su rečenice svojim obilježjima odgovarale četirima uvjetima, tako da je u ispitivanju bilo šest ispitnih podražaja po uvjetu. Sve su rečenice bile ujednačene po sljedećim kriterijima:

(1) glava relativne rečenice uvijek je bila subjekt glavne rečenice

(2) glava relativne rečenice uvijek je bila koordinirana skupina sastavljena od dviju imenica muškoga roda $u$ jednini.

Kriterijem (2) postignuta je višestruka mogućnost interpretacije u skladu s dizajnom prethodno provedenih istraživanja (v. poglavlje 1.2.). Sukladno istraživačkim pitanjima, razrađen je eksperimentalni nacrt $2 \times 2$ pri čemu je jedan fak- 
tor bio broj [množina, jednina] predikata relativne surečenice, a drugi padež ${ }^{6}$ [nominativ, akuzativ] relativne zamjenice. Faktorom broj manipuliran je broj predikata, a time i broj antecedenta subjekta relativne rečenice. Pretpostavlja se da će u rečenicama u kojima je upotrijebljena množina antecedent biti čitava koordinirana skupina, dok će u rečenicama u kojima je upotrijebljena jednina antecedent biti jedan od dvaju konjunkata. Drugim riječima, faktor broj služio je za manipulaciju vezanja relativne rečenice na antecedenta. Faktorom padež manipuliran je padež relativizatora, i to tako da je bio usklađen [nominativ] ili neusklađen [akuzativ] s padežom glave, tj. koordinirane skupine [nominativ]. Manipulacijom drugoga faktora istražuju se poteškoće obrade koje su već uočene za objektne relativne rečenice (primjerice, Friedmann i Novogrodsky 2004, Balija i dr. 2012). To je ukupno činilo 4 eksperimentalna uvjeta: (1) uvjet usklađenoga broja i padeža; (2) uvjet neusklađenoga broja; (3) uvjet neusklađenoga padeža i (4) uvjet neusklađenoga broja i padeža (Tablica 2). Sve su rečenice ujednačene po duljini, što je posebice važno u analizi podataka prikupljenih metodom praćenja pokreta očiju. Osim toga, sve su započinjale uvodnim dijelom koji je sadržavao priložnu oznaku i bezlični glagol u 3. licu množine (,U priči se pojavljuju...”, „U članku se spominju...” i „Na slici se prikazuju...”).

Kako sudionici ne bi proniknuli u svrhu istraživanja, oblikovan je i jednak broj umetnutih podražaja (24), a svi su bili ujednačeni po sljedećim kriterijima:

(1) subjekt glavne rečenice bila je koordinirana skupina sastavljena od dviju imenica ženskoga roda

(2) umetnuti podražaji bili su priložne, a ne relativne rečenice.

Tablica 2 prikazuje faktore, eksperimentalne uvjete i umetnute podražaje, a uz uvjet i umetnuti podražaj navedeni su primjeri. ${ }^{7}$

\footnotetext{
${ }^{6}$ Kako nas u radu ponajprije zanima utječe li sročnost na odabir antecedenta te budući da je odnos padeža i uloge jedinstven, drugi je faktor iskazan padežom, a ne ulogom koordinirane skupine i relativizatora $u$ rečenici.

7 Zbog ujednačenosti uvodnoga dijela u rečenicama sva četiri uvjeta, taj dio nije naveden u Tablici 2. Izdvojeni su isključivo oni dijelovi koji su relevantni za faktorijalni nacrt eksperimenta i obradu podataka. Puni se primjer može vidjeti u nastavku (5).
} 
Tablica 2. Prikaz faktora ispitivanja, eksperimentalnih uvjeta te umetnutih podražaja s primjerima

Faktori ispitivanja

F1: Broj [mn; jd]

F2: Padež [nom; ak]

Eksperimentalni uvjeti i primjeri podražaja: ${ }^{8}$

(1) $\mathbf{m n}$ /nom: ... mljekar i mesar koji su ga poznavali [mljekar i mesar su poznavali nekoga]

(2) jd/nom: ... kirurg i anesteziolog koji ga je posjetio [kirurg je posjetio anesteziolo$\mathrm{ga} /$ anesteziolog je posjetio kirurga]

(3) mn/ak: ... pilot i marinac kojega su poslali [netko je poslao pilota/marinca]

(4) jd/ak: ... prodavač i zaštitar kojega je optužio [prodavač je optužio zaštitara/ zaštitar je optužio prodavača]

Umetnuti podražaji i primjeri:

(1) Veznik PA: Glumica i spisateljica bile su pet godina u Engleskoj pa su se vratile u Hrvatsku.

(2) Veznik ALI: Pjevačica i balerina nastupile su u američkom teatru, ali nisu očarale publiku.

Ispitivanje je provedeno dvjema metodama: (1) u odgođenome vremenu (upitnikom prosudbe) i (2) u stvarnome vremenu (metodom praćenja pokreta očiju; MPO). U Tablici 2 u zagradama su ponuđeni očekivani odgovori na postavljeno pitanje te je upravo upitnik prosudbe imao cilj utvrditi ostvaruju li se svi navedeni odgovori i u kojim omjerima. Iz pretpostavke da sročnost doprinosi odabiru antecedenta proizlazi da će u rečenicama (2), (3) i (4) iz Tablice 2, u kojima postoji dvostruka mogućnost interpretacije (slaganje s prvim ili drugim elementom koordinirane skupine) u većoj mjeri biti odabran linearno bliži (4c u nastavku; usp. \% u (3) prema Willer Gold i dr. 2016, 2018). Međutim, u rečenici (1), s obzirom na kombinaciju obilježja broja konjunkata koordinirane skupine i relativne zamjenice očekuje se da će za antecedenta relativne rečenice biti odabrana čitava koordinirana skupina (4a), što je u skladu s pretpostavkom prikazanom u (3').

\footnotetext{
8 N. B., razrješavanje antecedenta zamjenice ga relevantno je pitanje, no zbog prostornoga ograničenja u ovome radu nemamo prilike otvoriti raspravu na tu temu.
} 
Nadalje, budući da se iz roda, broja i padeža relativne zamjenice može iščitati rod, broj i padež antecedenta, ako je sročnost u podlozi toga vezanja, u ovome se uvjetu može očekivati najveće raspršenje, kao što je prikazano u primjeru 4.

(4) a. mljekar i mesar ${ }_{i}$ koji $_{\mathbf{i}}$ su ga poznavali

b. mljekar $_{i}$ i mesar koji ${ }_{i}$ su ga poznavali

c. mljekar i mesar $_{\mathrm{i}} \mathbf{k o j i}_{\mathrm{i}}$ su ga poznavali

Jedan od glavnih nedostataka metoda u odgođenome vremenu kao što su upitnici jest da one ne daju izravne podatke o automatskoj, nesvjesnoj razini jezične obrade. Metode u stvarnome vremenu poput metode praćenja pokreta očiju omogućuju upravo stjecanje uvida u vremenski tijek obrade, odnosno u automatske procese koji su u podlozi. Logička se pozadina temelji na činjenici da pokreti očiju nude izravan uvid u nesvjesne kognitivne procese (Just i Carpenter 1980). Iako se uporabom ove metode značajno usložnjava izvedba eksperimenta i kasnija analiza rezultata, premošćuju se gotovo svi nedostaci metoda u odgođenome vremenu, posebice nemogućnost mjerenja ispitanikova nesvjesnog odgovora na jezični podražaj (Marinis 2010). U skladu s navedenim, u ovome su istraživanju mjerenjima u odgođenome vremenu prikupljeni podatci o tumačenju rečenice post festum, na svjesnoj razini, dok se praćenjem pokreta očiju analizirala automatska obrada na nesvjesnoj razini.

Istraživanje u odgođenome vremenu provodilo se individualno, uporabom računalnoga programa IbexFarm (Drummond 2013). Prije ispitivanja potencijalnim je sudionicima (upitnik) predstavljen cilj istraživanja, nakon čega su oni zainteresirani potpisali pristanak za sudjelovanje. U upitniku se od sudionika tražilo da pažljivo pročitaju rečenicu prikazanu na zaslonu računala i da potom na postavljeno pitanje odgovore upisivanjem odgovora u predviđeno mjesto ( $k u c ́ i c u)$. Pitanje se svaki put pojavilo pet sekundi nakon prikazivanja rečenice i pitanja. Istaknuto je kako nije potrebno odgovarati punom rečenicom, već je dovoljno upisati dijelove rečenice ključne za odgovor na postavljeno pitanje. Svim su sudionicima nasumičnim redoslijedom prikazani svi podražaji u svim uvjetima, kao i umetnuti podražaji. Ispunjavanje upitnika trajalo je oko 20 minuta.

Ispitivanje u stvarnome vremenu također se provodilo individualno te je i ovim sudionicima prethodno predstavljen cilj istraživanja, a sudjelovanje je bilo dobrovoljno. Upotrijebljen je stacionarni uređaj za praćenje pokreta očiju (SMI Hi-Speed View 500), a sudionicima su nasumičnim redoslijedom prikazani 
svi podražaji. Kako bi se osiguralo da čitaju s razumijevanjem, nakon nekih je umetnutih i ispitnih podražaja uslijedilo i jednostavno pitanje s mogućnošću izbora. Budući da vrsta pitanja u ovakvim istraživanjima značajno može utjecati na izvedbu sudionika i narušiti prirodnost čitanja (posljedično i proces automatske obrade), pitanjem se nije provjeravalo tumačenje rečenice s obzirom na istraživačko pitanje (odabir antecedenta), već druge, za samo istraživanje irelevantne, informacije. Zadatak sudionika sastojao se u tome da pročitaju rečenicu s razumijevanjem te da po završetku čitanja pritisnu tipku miša. Pojedinačno je ispitivanje trajalo oko 20 minuta.

\subsection{Prikupljanje i obrada podataka}

Mjere upotrijebljene pri obradi podataka u upitniku prosudbe bili su odgovori na pitanja kojima se provjeravao odabir antecedenta relativne rečenice (v. Tablicu 2). U uvjetu [x/nom] (uvjet usklađenoga broja i padeža (1) i uvjet neusklađenoga broja (2)) to se ograničenje odnosi na subjekt, dok se u uvjetu [x/ak] (uvjet neusklađenoga padeža (3) i uvjet neusklađenoga broja i padeža (4)) ono odnosi na objekt rečenice ponuđene u odgovoru. Točnima su se smatrali odgovori u kojima se na mjestu relevantnoga argumenta (subjekta/objekta) pozivalo na imenice iz koordinirane skupine odgovarajućega podražaja. Netočnima su se smatrali preostali odgovori, odnosno a) pogrešni odgovori u kojima subjekt/objekt nedostaje ili se sudionik ne poziva na imenice iz koordinirane skupine odgovarajućega podražaja (primjerice, „Netko drugi je poznavao mljekara i mesara.”), ili pak b) neponuđeni odgovori (primjerice, ostavljanje praznoga mjesta predviđenog za odgovor ili davanje odgovora poput ,nije jasno”). Sukladno postojanju dvije skupine podataka, na podatcima prikupljenima upitnikom prosudbe provedene su dvije nezavisne statističke obrade podataka.

Podatci MPO prikupljeni su i obrađeni u programu SMI BeGaze koji čini dio programskoga paketa samog uređaja. Mjere upotrijebljene pri obradi podataka prikupljenih MPO temeljile su se na vremenu čitanja cijele rečenice i prethodno utvrđenih ciljanih regija, kao i na broju vraćanja pogleda na te regije. Ove su mjere uobičajene u istraživanjima obrade na rečeničnoj razini jer osvjetljavaju teškoće prilikom čitanja (dulje trajanje čitanja ili češće vraćanje na već pročitane dijelove). Mjere, a ujedno i zavisne varijable istraživanja, bile su: 
(1) trajanje prve fiksacije (u ms; govori o prvoj, tzv. nižoj razini sintaktičke obrade)

(2) ukupan broj fiksacija

(3) ukupno trajanje fiksacija (u ms; govori o strategijama obrade) ${ }^{9}$

(4) broj regresivnih pokreta oka u regiju interesa (vraćanje na već pročitano uslijed teškoća u obradi).

Te su se mjere promatrale na dvjema prethodno utvrđenim regijama interesa: (1) koordinirana skupina i (2) relativna zamjenica, kako je prikazano u primjeru (5):

(5) Na slici se prikazuju / (1) vozač i kontrolor / (2) koji ga je / pustio u autobus.

Statistička obrada podataka upitnika prosudbe i MPO izvršena je programom za statističku obradu $R$ (R Core Team 2017). Na podatcima upitnika prosudbe primijenjen je t-test čime su uspoređena po uvjetima tri tipa vezanja (cijela koordinirana skupina, hijerarhijski viši i linearno bliži konjunkt). Podatci MPO obrađeni su funkcijom $\operatorname{lm}$ (linearni model; $\operatorname{lm}(\mathrm{x} \sim \mathrm{y}$, data=z)). Funkcija $\operatorname{lm}$ na podatcima primjenjuje analizu kovarijance, koja višestrukom primjenom t-testova u odabranim uvjetima uspoređuje vrijednost zavisne varijable s obzirom na varijabilnost drugih nezavisnih varijabli. Statističkom obradom podataka prikupljenih MPO za svaku mjeru dviju regija interesa uspoređena su sva četiri uvjeta, pri čemu je zavisna varijabla (x) bila mjera, a nezavisna varijabla (y) uvjet. U nastavku se prikazuju glavni efekti i tendencije po uvjetima.

\section{Rezultati i rasprava}

Rezultati obrade točnih odgovora iz upitnika prosudbe za uvjet usklađenog broja i padeža $[\mathrm{mn} / \mathrm{nom}]$ pokazuju da su sudionici za antecedenta relativne rečenice birali cijelu koordiniranu skupinu, kao i oba elementa - linearno bliži i hijerarhijski viši (Grafikon 1). Provedena statistička obrada upućuje na statistički značajnu razliku između odabira čitave koordinirane skupine i linearno bližega (t: $-4,984, p<7,12 \mathrm{e}-05)$ te linearno bližega i hijerarhijski višega konjunkta (t: $-3,442, p<0,00258)$. Drugim riječima, rezultati pokazuju da se relativna reče-

9 Dulje trajanje fiksacija može biti pokazateljem većega kognitivnog napora i teškoća u obradi, primjerice teškoća dohvaćanja strukturnih ili značenjskih obavijesti tijekom čitanja; v. Holmqvist i dr. 2011. 
nica u različitim omjerima veže na hijerarhijski viši i linearno bliži konjunkt, kao i na cijelu koordiniranu skupinu, što sugerira postojanje trostrukoga izbora visine vezanja. Zanimljivo je primijetiti da su zabilježeni omjeri očekivani pod pretpostavkom da je visina vezanja motivirana procesima koji djeluju u podlozi sročnosti predikatnoga participa i koordinirane skupine (usp. Grafikon 1 i \% u (3)). Rezultati upitnika prosudbe dodatno pokazuju izrazito visok postotak vezanja na linearno najbližu imenicu u uvjetima koji prednost daju odabiru jednoga od dvaju antecedenata (uvjet neusklađenoga broja, uvjet neusklađenoga padeža i uvjet neusklađenoga broja i padeža) (Grafikon 1, stupac 2-4). U tim uvjetima nije zabilježen odabir čitave koordinirane skupine, već statistički značajna prednost odabira linearno bližega antecedenta u usporedbi s hijerarhijski višim $(\mathrm{p}<$ 2e-16). Zanimljivo je opaziti kako je najniži postotak odabira hijerarhijski višega konjunkta zabilježen u uvjetu neusklađenoga padeža. Izneseni rezultati stoga upućuju na preferenciju vezanja na linearno bliži konjunkt.

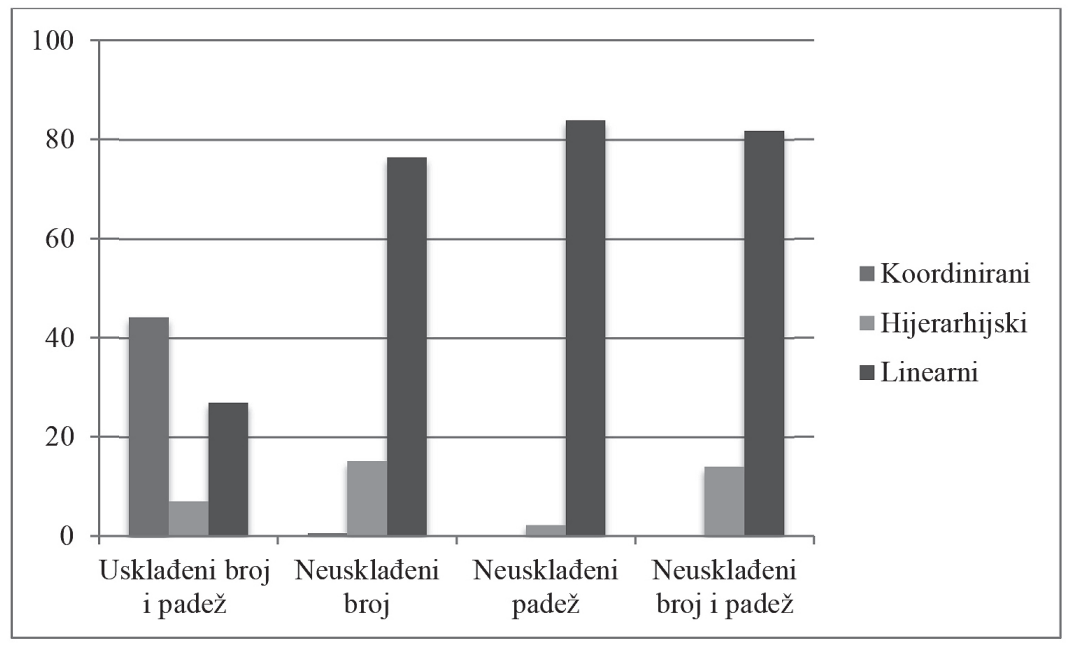

Grafikon 1. Preferencije vezanja: postotci točnih odgovora po uvjetima

Obraćajući pozornost na rezultate netočnih odgovora upitnika prosudbe, uz navedeno valja istaknuti da je najveći broj netočnih odgovora zabilježen u uvjetu usklađenoga broja i padeža [mn/nom] (Grafikon 2). ${ }^{10}$

\footnotetext{
${ }^{10}$ Rezultati t-testa potvrđuju postojanje statistički značajne razlike između vezanja na hijerarhijski viši konjunkt i netočnih odgovora u trima uvjetima u kojima su zabilježeni netočni odgovori (usklađenoga broja i padeža. $\mathrm{p}<0,01$; neusklađenoga padeža: $\mathrm{p}<0,0001$; neusklađenoga broja i padeža: $\mathrm{p}<0,0002$ ).
} 


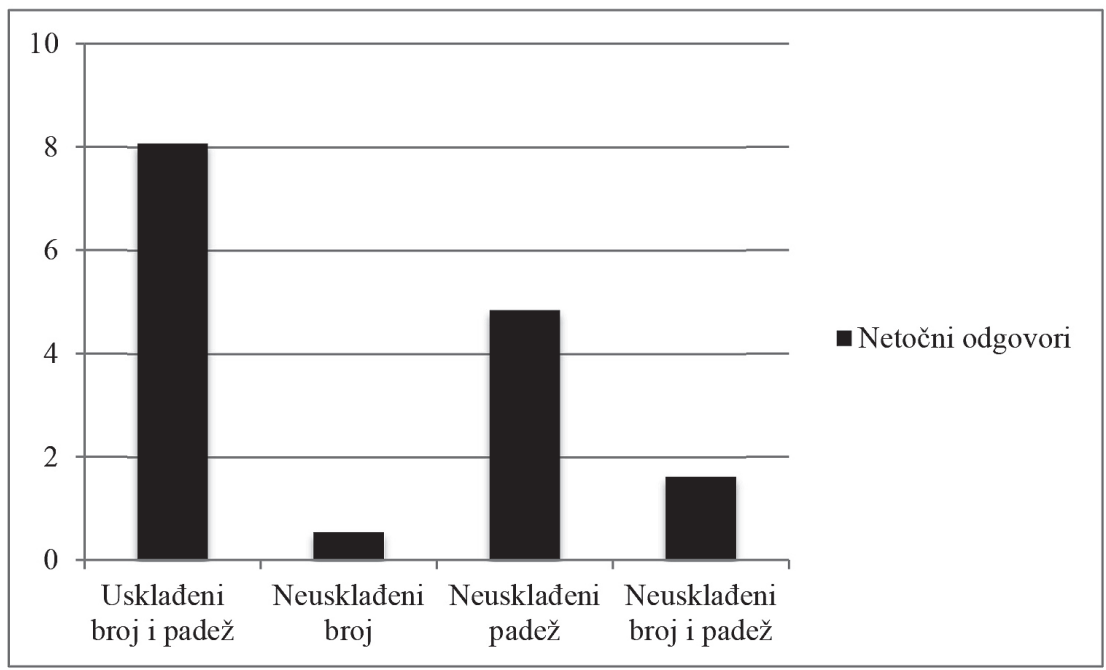

Grafikon 2. Preferencije vezanja: postotci netočnih odgovora po uvjetima

Rezultati dohvaćeni MPO upućuju na poteškoće u obradi za uvjete usklađenoga broja i padeža i neusklađenoga broja i padeža, posebice u regiji interesa „relativna zamjenica”. Valja naglasiti da su u nastavku izloženi rezultati na granici značajnosti te otvorenom ostaje mogućnost da bi veći broj podražaja ili ispitanika doprinio njezinomu povećanju. Tendencija za statističkom značajnošću zabilježena je prilikom analize tzv. kasnijih mjera jezične obrade, odnosno mjera (3) ukupno trajanje fiksacija (log vrijednost) (usklađeni broj i padež t: 1,834, p < 0,0693; neusklađeni broj i padež t: 1,813, p <0,0724) te (2) ukupan broj fiksacija (usklađeni broj i padež t: 1,729, $\mathrm{p}<0,0867$; neusklađeni broj i padež t: 1,946, $\mathrm{p}$ $<0,0544$ ) (Tablica 3). Za mjeru (4) broj regresivnih pokreta oka u regiju interesa dodatno se, na granici značajnosti, razlikovao uvjet neusklađenoga broja i padeža (t: 1,795, $\mathrm{p}<0,0754)$ (Tablica 3). 
Tablica 3. Regija interesa „relativna zamjenica”: srednje vrijednosti po ispitanicima (log vrijednosti u zagradi)

\begin{tabular}{l|l|l|l|l} 
& $\begin{array}{l}\text { Usklađeni broj } i \\
\text { padež }\end{array}$ & $\begin{array}{l}\text { Neusklađeni } \\
\text { broj }\end{array}$ & $\begin{array}{l}\text { Neusklađeni } \\
\text { padež }\end{array}$ & $\begin{array}{l}\text { Neusklađeni broj } i \\
\text { padež }\end{array}$ \\
\hline $\begin{array}{l}\text { Ukupno trajanje } \\
\text { fiksacija (ms) }\end{array}$ & $566,17(2,86)$ & $507,6(2,82)$ & $\begin{array}{l}460,21 \\
(2,77)\end{array}$ & $557,68(2,86)$ \\
\hline $\begin{array}{l}\text { Trajanje prve } \\
\text { fiksacije (ms) }\end{array}$ & $202,55(2,30)$ & $197,85(2,29)$ & $\begin{array}{l}199,52 \\
(2,29)\end{array}$ & $207,81(2,31)$ \\
\hline $\begin{array}{l}\text { Ukupan broj } \\
\text { fiksacija (N) }\end{array}$ & 16,85 & 14,59 & 13,79 & 17,27 \\
\hline $\begin{array}{l}\text { Broj regresivnih } \\
\text { pokreta (N) }\end{array}$ & 6,41 & 5,38 & 5,21 & 7,46 \\
\hline
\end{tabular}

Komplementarnost dviju metoda svoje opravdanje nalazi upravo u razmatranju rezultata uvjeta usklađenoga broja i padeža. Naime, isključivo je u tome uvjetu zabilježen ostvaraj svih triju strategija odabira antecedenta. Drugim riječima, rezultati obiju istraživačkih metoda sugeriraju da se u podlozi odabira antecedenta relativne zamjenice aktiviraju strategije prethodno predložene za sročnost koordinirane skupine s participskim predikatom (usp. (3) prema Willer Gold i dr. 2016, 2018). Ovaj zaključak nije u proturječju s pretpostavkom da već postojeći mehanizmi obrade u danome jeziku olakšavaju obradu složenijih struktura, već dapače dodatno implicira relevantnost njihove istovremene obrade. Drugim riječima, rezultati dobiveni objema metodama pokazuju da se govornici tijekom procesa razumijevanja oslanjaju na primjenu većega broja unutarjezičnih strategija koje podliježu istovremenoj obradi. U situacijama u kojima različite strategije rezultiraju većim brojem valjanih interpretacija rečenice obrada je znatno otežana. Dodatna potpora nedoumicama koje uzrokuje uvjet usklađenoga broja i padeža proizlazi iz opažanja da je najveći broj pogrešnih ili neponuđenih odgovora zabilježen upitnikom prosudbe upravo u tome uvjetu (Grafikon 2).

Provođenje više vremena i ponovno vraćanje na regiju ,relativna zamjenica” u uvjetu neusklađenoga broja i padeža razjašnjivo je obilježjima samoga uvjeta. Navedene teškoće u obradi dolaze iz dvaju izvora - neslaganja u padežu antecedenta [nom] i relativne zamjenice [ak] te neslaganja u broju predikata relativne rečenice [jd] i koordinirane skupine koja prethodi relativnoj rečenici [mn] (v. primjere u Tablici 2). Stoga je moguće da se upravo u uvjetu neusklađenoga broja i padeža prilikom čitanja i pokušaja interpretiranja rečenica javljaju teškoće u obradi i potreba za ponovnim čitanjem spornih dijelova. 


\section{Zaključak}

U ovome smo radu istražili utjecaj trostruke mogućnosti slaganja s koordiniranom imenskom skupinom na obradu i način vezanja relativne rečenice. Rezultati upitnika prosudbe, tj. odabira antecedenta u uvjetu (1) usklađenoga broja i padeža upućuju na utjecaj sročnosti na vezanje relativne rečenice. Pored vezanja na koordiniranu skupinu, upitnikom prosudbe zabilježena je snažna preferencija vezanja relativne rečenice na linearno bližu imenicu, koja prevladava nad vezanjem na hijerarhijski višu sastavnicu subjekta glavne rečenice. Stoga zaključujemo da relativna rečenica s koordiniranom imenskom skupinom podliježe zakonitostima prethodno uočenima za slaganje predikatnoga participa s koordiniranom skupinom u hrvatskome jeziku (Willer Gold i dr. 2016, 2018), što nije u potpunosti u skladu s dosad provedenim istraživanjima vezanja relativne rečenice sa složenom imenskom skupinom (primjerice, Lovrić i Fodor 2000, Matić 2018).

Rezultati dohvaćeni metodom praćenja pokreta očiju prije svega upućuju na poteškoće u obradi rečenica u uvjetu (1) usklađenoga broja i padeža, ali i u uvjetu (4) neusklađenoga broja i padeža. Navedene se teškoće u obradi očituju produljenim vremenom čitanja i većim brojem regresivnih pokreta oka. Poteškoće u obradi rečenica u prvome navedenom uvjetu u skladu su s rezultatima upitnika, a moguće ih je pripisati postojanju triju potencijalnih antecedenata relativne rečenice. Poteškoće u obradi rečenica u potonjem uvjetu, a koje nisu dohvaćene metodom u odgođenome vremenu, pokazatelj su automatskih procesa koji svoje utemeljenje imaju u jezično-specifičnim čimbenicima i očekivanjima samih govornika. Navedena problematika prelazi okvire ovoga rada jer dotiče pitanje strategija koje su u pozadini automatske obrade i kao takvu ju valja dodatno istražiti. Osim toga, ona predstavlja potvrdu važnosti kombiniranja metoda u odgođenome i stvarnome vremenu s ciljem stjecanja cjelovite slike o mehanizmima obrade.

Zaključno, rezultati dvaju eksperimenata u ovome radu pokazuju da je odabir antecedenta s jedne strane olakšan sročnošću, dok su s druge strane raznovrsnost strategija i njihova istovremena primjena uzrokom teškoća u obradi. Provedeno ispitivanje stoga u jednakoj mjeri upućuje na potrebu za istraživanjem jezično-specifičnih čimbenika koji utječu na odabir i način vezanja relativne rečenice s ciljem širenja spoznaja o jezičnoj obradi općenito, kao i za eksperimentalnim istraživanjima slaganja u hrvatskome. 


\section{Literatura:}

Abdelghany, Hala; Fodor, Janet D. 1999. Low attachment of relative clauses in Arabic. Izlaganje na konferenciji Architectures and Mechanisms of Language Processing (AMLaP). Edinburgh.

Balija, Maja; Hržica, Gordana; Kuvač Kraljević, Jelena. 2012. Odnosne rečenice bez pomaka i traga: proizvodnja odnosnih rečenica kod djece s posebnim jezičnim teškoćama. Suvremena lingvistika 38/74. 139-154.

Bock, Kathryn; Miller, Carol A. 1991. Broken agreement. Cognitive Psychology 23/1. 45-93.

BošKović, ŽELJKO. 2009. Unifying first- and last-conjunct agreement. Natural language and linguistic theory 27/3. 455-496.

Brysbaert, Marc; Mitchell, Don C. 1996. Modifier attachment in sentence processing: Evidence from Dutch. The Quarterly Journal of Experimental Psychology 49A. 664695.

Carreiras, Manuel; Clifton, Charles. 1999. Another word on parsing relative clauses: Eyetracking evidence from Spanish and English. Memory \& cognition 27/5. 826-833.

Cuetos, Fernando; Mitchell, Don C. 1988. Cross-linguistic differences in parsing: Restrictions on the use of the Late Closure Strategy in Spanish. Cognition 30. 73-105.

Cuetos, Fernando; Mitchell, Don C.; Corley, Martin M. B. 1996. Par sing in different languages. Language Processing in Spanish. Ur. Carreiras, Manuel; García-Albea, José; Sebastián-Gallés, Núria. Lawrence Erlbaum. Hillsdale. 145-187.

Drummond, Alex. 2013. Ibex Farm [Računalni program]. http://spellout.net/ibexfarm/ (pristupljeno u ožujku 2018).

EHRLICH, KAREN I DR. 1999. Low attachment of relative clauses: New data from Swedish, Norwegian and Romanian. Poster izložen na 12. godišnjoj CUNY konferenciji o sintaktičkoj obradi (12th annual CUNY conference on human sentence processing). City University of New York.

Eysenck, Michael W.; Keane, Mark T. 2015. Cognitive psychology: A student's handbook. Psychology Press. New York.

FERnÁNDEZ, Eva M. 2003. Bilingual sentence processing: relative clause attachment in English and Spanish [Language Acquisition and Language Disorders, Vol. 29]. John Benjamins Publishing. USA.

Fodor, Jerry A. 1983. The Modularity of Mind. MIT Press. Cambridge.

Franck, Julie; Vigliocco, Gabriella; Nicol, Janet. 2002. Subject-verb agreement errors in French and English: The role of syntactic hierarchy. Language and Cognitive Processes 17/4. 371-404. 
FrAZIER, Lyn. 1979. On comprehending sentences: syntactic parsing strategies. Doktorska disertacija. Sveučilište u Connecticutu.

Frazier, Lyn; Clifton, Charles. 1996. Construal. Mit Press.

Frazier, Lyn; Clifton, Charles. 1997. Construal: Overview, motivation, and some new evidence. Journal of Psycholinguistic Research 26/3. 277-295.

Frazier, Lyn; Fodor, JANet D. 1978. The sausage machine: a new two stage parsing model. Cognition 6. 291-326.

Friedmann, NaAma; Novogrodsky, Rama. 2004. The acquisition of relative clause comprehension in Hebrew: A study of SLI and normal development. Journal of Child Language 31/3. 661-681.

GiBSON, EdwARD. 1998. Linguistic complexity: locality of syntactic dependencies. Cognition 68. 1-76.

Grillo, Nino; Costa, JoÃo. 2014. A novel argument for the Universality of Parsing principles. Cognition 133. 156-187.

Hemforth, Barbara I DR. 2015. Relative clause attachment in German, English, Spanish and French: effects of position and length. Lingua 166. 43-64.

Hemforth, Barbara I DR. 1998. Syntactic ambiguity resolution in German. Syntax and semantics (Vol 31). Sentence processing: A crosslinguistic perspective. Ur. Hillert, Dieter. Academic Press. London. 293-312.

HolmQvist, Kenneth i DR. 2011. Eye tracking: A comprehensive guide to methods and measures. OUP Oxford.

Just, Marcel A.; Carpenter, Patricia A. 1980. A Theory of Reading: From Eye Fixations to Comprehension. Psychological Review 87/4. 329-354.

Keung, Lap-Ching; Staub, Adrian. 2018. Variable agreement with coordinate subjects is not a form of agreement attraction. Journal of Memory and Language 103. 1-18.

Kordić, SnježAna. 1995. Relativna rečenica. Matica hrvatska. Zagreb.

Lovrić, NenAd; Fodor, JANet D. 2000. Relative clause attachment in sentence parsing. Poster izložen na 13. godišnjoj CUNY konferenciji o sintaktičkoj obradi (13th annual CUNY conference on human sentence processing). City University of New York.

Marinis, THEOdor. 2010. Using on-line processing methods in language acquisition research. Experimental Methods in Language Acquisition Research. Ur. Unsworth, Sharon; Blom, Elma. John Benjamins: Language Learning and Language Teaching. $139-162$.

Marušič, Franc; Nevins, Andrew I.; Badecker, William. 2015. The grammars of conjunction agreement in Slovenian. Syntax 18/1. 39-77.

Matić, Ana; Kuvač Kraljević, Jelena. 2017. Razumijevanje sintaktičkih struktura u odrasloj dobi - podatci s TROG-2:HR testa. Logopedija 7/2. 42-48. 
Matić, Ana. 2018. The influence of structural-semantic factors on parsing strategies and attachment preferences in Croatian. 6th Young Linguists' Meeting in Poznań: From exploration to explanation in the study of language. Book of Abstracts. Cambridge University Press. 62-63.

Miyamoto, Edson T. 1998. Relative clause processing in Brazilian Portuguese and Japanese. Doktorska disertacija. Massachusetts Institute of Technology.

Murphy, Andrew; PušKar, Zorica. 2018. Closest conjunct agreement is an illusion. Natural Language and Linguistic Theory 36/4. 1207-1261.

Papadopoulou, Despoina. 2006. Cross-linguistic variation in sentence processing: Evidence from $R C$ attachment preferences in Greek (Vol 36). Springer Science \& Business Media.

Papadopoulou, Despoina; Clahsen, Harald. 2003. Parsing strategies in L1 and L2 sentence processing: A study of relative clause attachment in Greek. Studies in Second Language Acquisition 25/4. 501-528.

R Core Team. 2017. $R$ : A language and environment for statistical computing. $R$ Foundation for Statistical Computing. Vienna, Austria. URL https://www.R-project.org/.

Traxler, Matthew J.; Pickering, Martin J.; Clifton Jr., Charles. 1998. Adjunct attachment is not a form of lexical ambiguity resolution. Journal of Memory and Language 39/4. 558-592.

Van Gompel, Roger P. G.; Pickering, Martin J. 2007. Syntactic parsing. The Oxford handbook of psycholinguistics. Ur. Gaskell, M. Gareth i dr. SAD. Oxford University Press. 289-307.

Willer Gold, Jana I DR. 2016. Conjunct Agreement and Gender in South Slavic: From Theory to Experiments to Theory. Journal of Slavic Linguistics 24/1. 187-224.

WILLER Gold, JANA I DR. 2018. When linearity prevails over hierarchy in syntax. PNAS 115/2. 495-500.

\section{Relative Clause Attachment to a Coordinated Phrase in Croatian: a Psycholinguistic Perspective}

\section{Abstract}

The language-specific phenomena underlying automatic sentence processing and interpretation have long been the topic of psycholinguistic investigations. Recent studies on processing relative clauses and the strategies that influence attachment preferences have shed new light on this question.

Despite the well-attested observation that the structure of the complex noun phrase preceding the relative clause can influence sentence processing, the effect of the 
structural relations on attachment preferences still remains unclear. Therefore, current study examines sentence processing and attachment preferences in relative clauses headed by coordinated structure. The two main aims of this study are: 1) to establish attachment preferences and 2) to investigate language-specific constraints affecting these preferences.

In total, 62 native adult speakers of Croatian language participated in the study. The study combined offline and an online method; the attachment preference questionnaire and the eye-tracking methodology. The results indicate strong preference towards the linearly closer antecedent (low attachment), as opposed to hierarchically higher (high attachment). The data further indicate that the conjunct agreement facilitates, while the parallel availability of multiple interpretations hinders the processing of relative clauses.

These findings support the initiative to study language-specific phenomena that affect attachment preferences as these contribute to broadening our understanding of language processing in general, as well as to experimental investigations of various language-specific phenomena.

Ključne riječi: rečenična obrada, preferencije vezanja, relativna rečenica, koordinirana skupina, upitnik prosudbe, praćenje pokreta očiju

Keywords: sentence processing, attachment preferences, relative clause, coordination, questionnaire, eye-tracking 